RESEARCH PAPER

\title{
Airway disease risk from environmental tobacco smoke among coffeehouse workers in Turkey
}

\author{
F Fidan, A H Cimrin, G Ergor, C Sevinc
}

Tobacco Control 2004;13:161-166. doi: 10.1136/tc.2003.003731

See end of article for authors' affiliations ....................

Correspondence to: A H Cimrin, Dokuz Eylul University Medical Faculty, Chest Department, 1440 SK 18/5 Karaferya Apt, Alsancak Izmir 35220, Turkey;

acimrin@deu.edu.tr

Received 3 March 2003 Accepted 8 December 2003

Objectives: To examine the effect of ETS exposure on respiratory symptoms and pulmonary function and to compare workers in coffeehouses to those in other occupations in order to assess the risk of respiratory illness in this occupation.

Design: Cross sectional study.

Setting: The study area consisted of the three metropolitan districts of the city of Izmir, Turkey. 86 coffeehouses and 80 other small scale shops which had no known respiratory risk factor, located in the same area, were taken as the study group.

Subjects: 207 workers were assessed.

Main outcome measurements: Subjects answered a questionnaire about demographic and working characteristics, respiratory symptoms, and smoking behaviour. Physical examinations and spirometric measurements were carried out at the workplaces.

Results: There was a significant increase in respiratory symptoms in coffeehouse workers. Working in a coffeehouse showed a significant risk for chronic bronchitis (odds ratio (OR) 4.3). In coffeehouse workers, forced expiratory volume in one second $\left(\mathrm{FEV}_{1}\right)$ decreased $5.1 \%$, forced vital capacity (FVC) $3.4 \%, \mathrm{FEV}_{1} /$ FVC 1.6\%, peak expiratory flow (PEF) $6.45 \%$, and forced expiratory flow $\left(\mathrm{FEF}_{25}\right) 7.2 \%, \mathrm{FEF}_{50} 10 \%$, and $\mathrm{FEF}_{25-75} 9.8 \%$. Among workers who were described as having an "airway disease", coffeehouse workers were significantly greater in number. When age, body mass index, and smoking behaviour were controlled, working in a coffeehouse was strongly associated with "airway disease" compared to other workers (OR 5.35, 95\% confidence interval 2.41 to 11.87 ).

Conclusions: Workers in coffeehouses showed significant increases in respiratory symptoms and decreased pulmonary function. All workers need to gain an awareness of these occupational risks and working conditions should be improved immediately.

$\mathrm{E}$ nvironmental tobacco smoke (ETS) is a known risk factor for acute and chronic conditions, mainly in the respiratory system in children and adults. As smoking is not banned in most public places it is widespread in settings where people gather together for economic, social, and cultural reasons. Cafes, restaurants, bars, and other sites for relaxing and fun are usually filled with heavy smoke. People visiting these places, even if they do not smoke, are exposed to passive smoking. In particular the people who work in these settings are under continuous exposure.

Cafes are a significant part of daily life in many parts of the world. Turkish coffeehouses called "kahvehane" were first introduced in Istanbul from Syria in 1555. Since then, they have become scattered all over the rural and urban parts of the country. Coffeehouses are large rooms with tables and chairs, with a small kitchen place in one corner, and are typically located in the basement floor of buildings.

Most men spend a considerable amount of time in these places during the day and after work. Especially in lower socioeconomic neighbourhoods these coffeehouses are more densely located where unemployment is more frequent and men spend most of the day in these closed environments (fig 1).

Smoking prevalence is $50-60 \%$ in men in Turkey. ${ }^{1}$ The law banning smoking in public places has been in effect since 1996 in Turkey. These public places are government buildings, cultural and educational settings, and public transportation areas. Privately owned small scale enterprises are not covered by this law. Although the public places mentioned in the law does not specifically state coffeehouses, bars, and restaurants, some provide non-smoking areas as a result of the awareness created by the regulations. However, the population visiting the coffeehouses are mostly heavy smokers and this is one of the reasons they like to spend time in these places. Therefore, it is almost impossible to prevent smoking in coffeehouses. Smoking is also allowed in other small shops; however, passive smoke is not an issue because customers stay in these shops only for a short period of time.

ETS would be expected to affect coffeehouse workers most, since they spend considerably longer time compared to customers in these places. However, these effects regarding public and occupational health have not been investigated.

The aim of this study is to examine the effect of ETS exposure on respiratory symptoms and pulmonary function and to compare the coffeehouse workers to men in other occupations in order to assess the risk of respiratory illness in this occupation.

\section{METHODS}

\section{Study population}

Izmir is the third biggest city in Turkey with a population of almost 3,5 million. The study area consisted of the three metropolitan districts of the city of Izmir, Turkey. It was not possible to find a complete list of coffeehouses to constitute a sample frame because they are not inspected or registered properly. This was also relevant for all other small scale

Abbreviations: $\mathrm{BMI}$, body mass index; $\mathrm{Cl}$, confidence interval; ETS, environmental tobacco smoke; $F E F$, forced expiratory flow; $\mathrm{FEV}_{1}$, forced expiratory volume in one second; FVC, forced vital capacity; OR, odds ratio; PEF, peak expiratory flow 


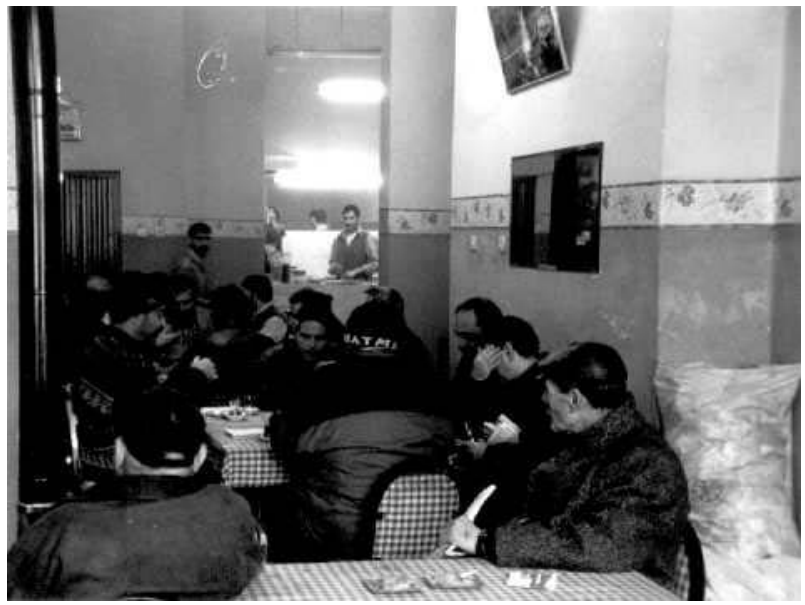

Figure 1 General view of a Turkish coffeehouse-"kahvehane".

enterprises. Under the circumstances, we decided to include all coffeehouses in the defined geographic area. The coffeehouses were identified by walking along each street in the three districts. The small scale shops were identified as the closest to the coffeehouse. The shops were convenience stores, stationary shops, grocers, butchers, plumbers, etc. Hair saloons, barbershops, and bakery type workplaces were excluded because of possible occupational respiratory risk factors. The employees who worked previously in shoemaking, painting, mining, textile, and other sectors carrying respiratory risks were also excluded from the study.

All employees in the coffeehouses were included in the study. The coffeehouse workers and the customers share the same space since these places did not have any partitioning to separate them. Therefore everyone was exposed to ETS.

\section{Occupational history}

The work history of the subjects was assessed through a structured questionnaire which included questions on previous and current jobs, job description, working conditions, exposures to any chemical substances and dust, ventilation conditions of the workplace, and total and daily working time.

\section{Ascertainment of respiratory effect}

All participants were informed of the study and their consent obtained. The face to face interview was conducted using the respiratory illness questionnaire adapted from the American Thoracic Society which also included demographic characteristics, work history, and working conditions. ${ }^{2}$ In addition physical examinations and spirometric measurements were carried out at the workplaces. The physical examination of all the subjects was carried out by the same respiratory disease specialist. Spirometric measurements were obtained by the same physician using a portable spirometry according to the criteria of the American Thoracic Society. ${ }^{3}$ Three consecutive measurements were taken and the best value was recorded for forced expiratory volume in one second $\left(\mathrm{FEV}_{\mathrm{I}}\right)$, forced vital capacity (FVC), $\mathrm{FEV}_{1} / \mathrm{FVC}$, peak expiratory flow (PEF), and four parameters of forced expiratory flow: $\mathrm{FEF}_{25}, \mathrm{FEF}_{50}$, $\mathrm{FEF}_{75}$, and $\mathrm{FEF}_{25-75}$.

Heights and weights of the study group were measured and body mass indexes (BMI) were calculated according to the formula: weight $(\mathrm{kg}) /$ height $\left(\mathrm{m}^{2}\right)$. BMI was categorised into two groups: $<25$ and $\geqslant 25$. Smoking status was grouped as current smokers, never smokers, and ex-smokers.

The symptoms assessed through the interview were cough, wheezing, phlegm, and dyspnoea. Chronic bronchitis was defined as presence of coughing or phlegm on most days lasting three months or more for over two years. ${ }^{4-6}$

In the physical examination, the lengthening of expirium, rhonchii in auscultation, and wheezing were the pathologic signs indicative of airway disease. Airway disease was defined as chronic bronchitis and/or pathologic signs in auscultation and at least two respiratory symptoms and/or $\mathrm{FEV}_{1} / \mathrm{FVC}<70 \%$ on spirometry. ${ }^{5-7}$

\section{Statistical analysis}

The coffeehouse workers and the small shop owners were compared for baseline characteristics. Student's $t$ test was performed to compare age, height, weight, BMI, and spirometric results. Mean and standard deviations were calculated for years at work, age at starting smoking, and pack-years smoked. Using the $\chi^{2}$ test, the significance of other characteristics - that is, demographics, smoking status, past ETS exposure, chronic bronchitis, physical examination findings, and presence of airway disease-were evaluated.

After the assessment of airway disease according to the criteria described above, the study group was categorised as cases that had the condition and controls that do not. To determine the risk of occupation (coffeehouse worker) on airway disease, univariate analysis and logistic regression were conducted. A model was constructed including age, smoking status, BMI, and years at work as confounding factors to obtain adjusted odds ratios (OR) for occupation. An additional model was used for smokers only adjusted for pack-years of smoking. To assess the dose-response relation of ETS to airway disease the working duration was categorised by the quartile values. The risk to coffeehouse workers was assessed by the OR taking other workers as the reference category. $\chi^{2}$ for trend analysis was conducted for significance of the results.

\section{RESULTS}

\section{General findings}

The study was conducted between January 2000 and December 2001. Among the 86 coffeehouses in the three districts, 10 refused to participate in the study. A total of 114 coffeehouse workers and 93 workers in 80 small shops were assessed.

\section{Demographic characteristics}

All the participants were male and the coffeehouse workers and the other workers were similar in age, height, weight, and BMI $(\mathrm{p}>0.05)$ (table 1$)$.

\section{Cigarette smoking and ETS}

The rate of smoking in their homes, currently smoking, and during childhood was $66.7 \%$ in the coffeehouse workers and was not significantly different from the other group $(\mathrm{p}=0.203$ and 0.07$)$. Smoking was highly prevalent in both groups, $86 \%$ in coffeehouse workers and $76 \%$ in the other group. There was no significant difference in smoking status between the two groups $(\mathrm{p}=373)$. Mean (SD) age of starting smoking was $17.6(5.3)$ and 19.0 (6.7) in the other group $(\mathrm{p}=0.137)$. The pack years of smoking were also not significantly different in the two groups when categorised as less than 20 pack years or more $(p=0.216)$ (table 2$)$.

\section{Working conditions}

The mean (SD) working years of coffeehouse workers was 10.9 (10.6) (range 1-50) and daily working hours were 11.7 (1.8) and 6.8 (0.5) days a week. In the group of other workers, the mean working years were 12.8 (10.4) (range $1-42)$ and daily working hours were 10.9 (2.4) and 6.9 (0.3) days a week. 
Table 1 Characteristics of the workers

\begin{tabular}{llll}
\hline & $\begin{array}{l}\text { Coffeehouse workers } \\
(\mathbf{n}=114) \\
\text { Mean (SD) }\end{array}$ & $\begin{array}{l}\text { Other occupations } \\
(\mathbf{n}=\mathbf{9 3}) \\
\text { Mean (SD) }\end{array}$ & p Value \\
\hline Age & $38.54(13.30)$ & $39.59(12.84)$ & 0.772 \\
Height & $171.51(07.58)$ & $171.83(06.61)$ & 0.453 \\
Weight & $71.90(12.73)$ & $72.95(10.60)$ & 0.135 \\
Body mass index & $24.43(04.00)$ & $24.70(03.31)$ & 0.333 \\
\hline
\end{tabular}

Table 2 Smoking status and history of study groups

\begin{tabular}{|c|c|c|c|c|c|}
\hline & \multicolumn{2}{|c|}{$\begin{array}{l}\text { Coffeehouse workers } \\
(\mathrm{n}=114)\end{array}$} & \multicolumn{2}{|c|}{$\begin{array}{l}\text { Other occupations } \\
(\mathrm{n}=93)\end{array}$} & \multirow[b]{2}{*}{ p Value } \\
\hline & $n$ & $\%$ & $n$ & $\%$ & \\
\hline Non-smoker & 13 & 11.4 & 17 & 18.2 & \\
\hline Ex-smoker & 3 & 2.6 & 2 & 2.2 & \\
\hline Current smoker & 98 & 86.0 & 74 & 79.6 & 0.373 \\
\hline$>20$ pack years & 56 & 55.4 & 35 & 46.1 & 0.216 \\
\hline \multicolumn{6}{|l|}{ ETS } \\
\hline Home (current) & 57 & 50.0 & 34 & 36.6 & 0.053 \\
\hline Childhood (past) & 76 & 66.7 & 54 & 58.1 & 0.203 \\
\hline Mean (SD) age at starting smoking & \multicolumn{2}{|c|}{$17.6(5.3)$} & \multicolumn{2}{|c|}{$19.0(6.7)$} & 0.137 \\
\hline
\end{tabular}

The average working area in the coffeehouses were 119.5 (66.8) $\mathrm{m}^{2}$ and mean number of customers daily was 114.7 (111.5). There was some type of air ventilation system in $91.2 \%$ of the coffeehouses.

In the small shops, the average working area was 54.2 (33.7) $\mathrm{m}^{2}$ and mean number of daily clients was 89.4 (64.6). In these small shops a maximum of two people were employed.

Clients usually spent short periods of time in the shops and were not likely to smoke during these visits. None of these workplaces had a special ventilation system.

\section{Respiratory symptoms}

Respiratory symptoms were significantly higher in coffeehouse workers than the other occupational groups (table 3).

These symptoms included morning coughs, frequent coughing, coughing for more than three months, and having these symptoms for more than two years $(p<0.05)$.
Chronic bronchitis was diagnosed in $16.7 \%$ of coffeehouse workers and $4.3 \%$ of the other group. This difference was significantly higher $(\mathrm{p}=0.005)$. When controlled for age, BMI, and smoking status in the logistic regression, working in the coffeehouse showed a significant risk (OR 4.3, 95\% CI 1.3 to 5.3 ) (table 3 ).

\section{Clinical and spirometric findings}

There were pathologic auscultation findings in $39.5 \%$ of the coffeehouse workers and $10.8 \%$ of the other group by physical examination. The auscultation findings supporting airway disease were significantly higher in the coffeehouse workers $(\mathrm{p}=0.0001)$.

Table 4 shows the percentage of expected spirometric findings in each group. $\mathrm{FEV}_{1}, \mathrm{PEF}, \mathrm{FEF}_{25}, \mathrm{FEF}_{50}, \mathrm{FEF}_{25-75}$ levels in the coffeehouse workers were significantly lower for the predicted percentage values.

\begin{tabular}{|c|c|c|c|c|c|c|}
\hline & & $\begin{array}{l}\text { Coffeehouse } \\
\text { workers (\%) }\end{array}$ & $\begin{array}{l}\text { Other occupations } \\
\text { (\%) }\end{array}$ & $\mathrm{p}$ Value & OR & $\% 95 \mathrm{Cl}$ \\
\hline \multicolumn{7}{|l|}{ Symptoms } \\
\hline & Coughing & 26.30 & 9.70 & 0.002 & 3.41 & 1.48 to 7.86 \\
\hline & Phlegm & 36.80 & 17.20 & 0.002 & 2.67 & 1.34 to 5.31 \\
\hline & Dyspnoea & 43.00 & 12.90 & 0.000 & 5.94 & 2.76 to 12.75 \\
\hline & Wheeze & 27.20 & 10.80 & 0.003 & 3.23 & 1.41 to 7.36 \\
\hline \multicolumn{7}{|l|}{ Findings } \\
\hline & $\begin{array}{l}\text { Pathological } \\
\text { auscultation } \\
\text { Diminished breath }\end{array}$ & 39.50 & 10.8 & 0.000 & 6.02 & 2.70 to 13.42 \\
\hline & sounds & 28.90 & 4.30 & 0.000 & 9.41 & 3.02 to 26.30 \\
\hline & Lengthened expirium & 17.50 & 1.10 & 0.000 & 25.60 & 3.19 to 205.43 \\
\hline & Crackles & 3.50 & 1.10 & 0.257 & 2.29 & 0.21 to 24.70 \\
\hline & Ronchi & 14.90 & 5.40 & 0.027 & 3.35 & 1.11 to 10.09 \\
\hline \multicolumn{7}{|l|}{ Diagnosis } \\
\hline & Chronic bronchitis & 16.70 & 4.30 & 0.005 & 4.32 & 1.34 to 5.31 \\
\hline & Airway disease & 38.60 & 11.80 & 0.000 & 5.03 & 2.36 to 10.72 \\
\hline
\end{tabular}

*Adjusted for age, smoking, BMl, and years at work

$\mathrm{Cl}$, confidence interval; $\mathrm{OR}$, odds ration. 
Table 4 Spirometric findings of the workers

\begin{tabular}{|c|c|c|c|}
\hline \multirow[b]{2}{*}{ Parameter } & \multirow[b]{2}{*}{ Group } & \multicolumn{2}{|l|}{$\%$ predicted value } \\
\hline & & Mean (SD) & p Value \\
\hline \multirow[t]{2}{*}{$\mathrm{FEV}_{1}$} & Coffeehouse workers & $89.37(16.17)$ & 0.011 \\
\hline & Other occupations & 94.47 (12.42) & \\
\hline \multirow[t]{2}{*}{ FVC } & Coffeehouse workers & $86.70(15.10)$ & 0.080 \\
\hline & Other occupations & $90.16(12.67)$ & \\
\hline \multirow[t]{2}{*}{$\mathrm{FEV}_{1} / \mathrm{FVC}$} & Coffeehouse workers & $85.83(10.76)$ & 0.250 \\
\hline & Other occupations & $87.43(08.74)$ & \\
\hline \multirow[t]{2}{*}{ PEF } & Coffeehouse workers & $68.99(21.13)$ & 0.026 \\
\hline & Other occupations & $75.44(19.97)$ & \\
\hline \multirow[t]{2}{*}{$\mathrm{FEF}_{25}$} & Coffeehouse workers & $72.56(24.58)$ & 0.027 \\
\hline & Other occupations & $79.84(21.77)$ & \\
\hline \multirow[t]{2}{*}{$\mathrm{FEF}_{50}$} & Coffeehouse workers & $84.06(29.14)$ & 0.006 \\
\hline & Other occupations & $94.22(23.56)$ & \\
\hline \multirow[t]{2}{*}{$\mathrm{FEF}_{75}$} & Coffeehouse workers & $106.89(31.60)$ & 0.254 \\
\hline & Other occupations & $101.44(36.01)$ & \\
\hline \multirow[t]{2}{*}{$\mathrm{FEF}_{25-75}$} & Coffeehouse workers & $88.07(28.67)$ & 0.009 \\
\hline & Other occupations & $97.94(24.28)$ & \\
\hline
\end{tabular}

Table 5 Effect of working in a coffeehouse on airway disease stratified by smoking

\begin{tabular}{|c|c|c|c|c|}
\hline & \multicolumn{2}{|l|}{ Smoker } & \multicolumn{2}{|l|}{ Non-smoker } \\
\hline & Airway disease & Normal & Airway disease & Normal \\
\hline $\begin{array}{l}\text { Coffeehouse } \\
\text { Other } \\
\text { Total } \\
\text { OR }(95 \% \mathrm{Cl}) \\
\text { Crude OR }(95 \% \mathrm{Cl}) \\
\text { M-H OR }(95 \% \mathrm{Cl})\end{array}$ & $\begin{array}{l}42 \\
11 \\
53 \\
4.21(1.88 \text { to } 9.59) \\
4.69(2.14 \text { to } 10.46) \\
4.52(2.04 \text { to } 10.20)\end{array}$ & $\begin{array}{r}59 \\
65 \\
124\end{array}$ & $\begin{array}{l}2 \\
0 \\
2 \\
3.09(0.18 \text { to } 98.64)\end{array}$ & $\begin{array}{l}11 \\
17 \\
28\end{array}$ \\
\hline
\end{tabular}

\section{Active and ETS effects on respiratory symptoms}

Working in a coffeehouse, without taking the confounding factors into consideration, had a strong effect on increasing the risk of respiratory illness (OR 4.69, 95\% CI 2.14 to 10.46). As seen in the stratified analysis the OR for working in a coffeehouse is 4.21 (95\% CI 1.88 to 9.59) among the smokers. When adjusted for smoking only the OR was 4.52 (table 5).

To determine the effect of active smoking in our data, when age, BMI, and occupation were controlled using logistic regression analysis, it was seen that the effect of smoking was high for airway disease (OR 6.96, (95\% CI 1.45 to 33.26) (table 6).

Controlling for the confounding factors, like age, BMI, smoking, and time in the occupation, the adjusted OR for the coffeehouse workers was 5.35 (95\% CI 2.41 to 11.87). When the analysis was conducted only for smokers and adjusted for the pack-years as well as the previously cited confounders the OR was 4.99 (95\% CI 2.18 to 11.43 ). As a result, working in the coffeehouse was found to be an independent risk factor for respiratory illness (table 6).
Analysing for the dose-response effect, when working in other occupational groups was considered as the reference category, the OR for working in the coffeehouse for $\leqslant 4$ years was 3.59, working for 5-12 years was 3.73, and it increased to 7.89 after 13 years $(\mathrm{p}<0.001)$.

\section{DISCUSSION}

Public places like bars, cafes, and restaurants, where people gather for social and cultural reasons, gain more importance each day in daily life. In Turkey, aside from the places mentioned above, coffeehouses ("kahvehane") have a traditionally very important role in the social life of the society. These places are not only social gathering areas but also places where men spend most of their time each day, especially in the rural areas where coffeehouses are the only social settings. These places offer very cheap services, where usually men from the middle or lower socioeconomic status attend, thus they do not have very desirable environmental conditions. Regarding the relation between smoking and socioeconomic level, and that on average there is one person

\begin{tabular}{lll} 
Table 6 Effect of smoking and occupation on airway disease & \\
\hline Factor & OR & $95 \% \mathrm{Cl}$ \\
\hline $\begin{array}{l}\text { Smoking } \\
\text { (adjusted for age, BMI, and occupation ) }\end{array}$ & 6.96 & 1.45 to 33.26 \\
$\begin{array}{l}\text { Working in the coffeehouse (crude) } \\
\text { Working in the coffeehouse (adjusted for smoking) }\end{array}$ & 4.69 & 2.14 to 10.46 \\
$\begin{array}{l}\text { Working in the coffeehouse (adjusted for age, BMl, smoking and time } \\
\text { in the occupation) }\end{array}$ & 4.52 & 2.04 to 10.20 \\
$\begin{array}{l}\text { Working in the coffeehouse -only for smokers (adjusted for the } \\
\text { pack-years as well as the previously cited confounders) }\end{array}$ & 5.35 & 2.41 to 11.87 \\
\hline
\end{tabular}


per one square metre area, it should not be hard to imagine the situation regarding cigarette smoke (ETS) in these coffeehouses.

It is impossible for the workers in such an area to avoid cigarette smoke. Coffeehouse employees spend almost 12 hours each day and everyday of the week in these small and insufficiently ventilated areas. The workers also smoked heavily and $86 \%$ were smokers. There was stability in the occupation since mean working time was more than 10 years.

Inhalation of tobacco smoke actively or passively causes conditions ranging from chronic bronchitis to chronic obstructive lung disease, which manifests in different respiratory symptoms.

There have been studies in the literature on ETS exposure at home that show significant increases in respiratory symptoms. ${ }^{8-10}$ Leuenberger et al found significant differences in a large group of non-smokers who have been exposed to ETS at home and at the workplace. ${ }^{4}$ Eisner reported an increase in respiratory symptoms in bartenders exposed to ETS. ${ }^{11}$ In our study, the findings underscore the fact that occupational exposure to ETS clearly constitutes a significant risk in coffeehouse workers. Dyspnoea, phlegm, wheezing, and coughing as well as chronic bronchitis were all seen more frequently in the coffeehouse workers compared to the other occupational groups. Chronic bronchitis was seen more among the coffeehouse workers compared to the other occupational groups, especially in the age group over 40 . However, the prevalence of chronic bronchitis in the younger age groups among the coffeehouse workers was also notable. It was also notable that the onset age for smoking was younger among this group (median age 16 years).

Working in a coffeehouse showed significant risks for coughing (OR 3.4), phlegm (OR 2.6), shortness of breath (OR 5.9), wheezing (OR 3.2), and chronic bronchitis (OR 4.3) when adjusted for the confounding variables. In accordance with these findings, as well as some of the spirometric findings, physical examination revealed auscultation results supporting the proposition that airway disease was significantly higher in the coffeehouse workers.

In studies where pulmonary functional changes in the people exposed to ETS both at home or in the work environment are measured, considerable changes have been assessed in $\mathrm{FEV}_{1}$ and $\mathrm{FVC},{ }^{210-17}$ in accordance with our findings.

Although in many of the studies the FEF $25-75$ levels were not presented, we have found an almost $10 \%$ decrease in coffeehouse workers which was also significantly lower than the other occupational groups. A decrease in this measure has been interpreted as an early predictor for small airway obstruction..$^{510} 15$ Hence, it could be said that working in a coffeehouse may have an effect on small airways.

Airway disease was significantly higher among the coffeehouse workers. After controlling for the effect of age, BMI, and smoking, working in the coffeehouse had an OR of 5.35 for airway disease. Thus, it could be said that working in a coffeehouse had a strong effect on airway disease. Smoking had an OR of 6.96 for airway disease after controlling for age, BMI, and occupation. Considering that the majority of the coffeehouse workers were smokers and that almost half of them smoked more than 20 pack years, they would be under greater risk for airway disease. Stratified analysis leads us to believe that there is an additional effect of ETS even among smokers. As the expected OR is lower in non-smokers, the confidence intervals show that it is not significant due to the fact that there are few non-smokers in the study.

In our study, coffeehouse workers and workers in other occupations did not differ in terms of age, BMI, or exposure to ETS outside the workplace. Workplace conditions, daily working times, and smoking behaviour were also similar in

\section{What this paper adds}

In the developing countries, workplaces such as coffeehouses have significant environmental tobacco smoke (ETS) exposure because of the presence of heavy smoking. Traditional coffeehouses - "kahvehane" - are common in eastern culture and these places have characteristics which are different to bars and restaurants in the western world. No research has been found in the literature about ETS in these workplaces and the respiratory effects on people. We wanted to investigate the effects of ETS on workers in these coffeehouses and how conditions compared to those in developed countries. We have found that, among coffeehouse workers in Turkey, ETS exposure at the workplace is a risk factor for airway disease, in addition to age and active smoking. It could be said that ETS is strongly associated with airway disease even among the smokers. Measures should be taken to prevent coffeehouse workers from being exposed to ETS. It is also a priority issue for the general public, given the wide use and geographical spread of coffeehouses.

both groups. Therefore, the reasons for developing airway disease were age and smoking in the other occupation groups and the coffeehouse workers; ETS at the workplace was an important additional factor.

Mark and colleagues found that respiratory symptoms ceased and FVC and $\mathrm{FEV}_{1}$ improved in the bartenders working in bars and taverns after a ban on smoking. ${ }^{11}$ Our findings also highlight that there needs to be efforts to increase smoking cessation in the coffeehouse workers. Banning smoking in these coffeehouses should be considered to prevent ETS exposure as a public health priority, both for the customers but more so for the workers in these places.

One notable limitation in our study was that the majority of subjects were active smokers, which is not ideal when trying to assess the effect of passive smoke. However, it was almost impossible to compile a group of non-smoking coffeehouse workers. The reasons for choosing the coffeehouse as the workplace was because of the very smoky atmosphere characteristic of these establishments, and because these places are also open to the general public. Lack of ETS exposure measurements such as cotinine or hair nicotine levels also might be a limitation of the study.

In conclusion, working in a coffeehouse does not only result in respiratory symptoms and mild pulmonary functional changes but also significant obstructive airway disease. Working conditions seem to act independently from active smoking in the development of airway disease, which increases with the working duration. All workers have to be made aware of the occupational risks, and working conditions should be improved immediately where ETS is present.

ETS is especially important in coffeehouses, because these closed environments are small places where large numbers of people visit and spend long hours. The observed respiratory effects in the coffeehouse workers are also a threat to the general public, as well as being an occupational risk, since they share the same environment with the customers. Thus, there is an urgent need to reduce active smoking in the population as well as eliminating ETS, especially in public places. We believe that our results will contribute to the development of new regulations concerning public places and the enforcement of the present law.

\section{Authors' affiliations}

F Fidan, A H Cimrin, G Ergor, C Sevinc, Dokuz Eylul University Medical Faculty, Chest and Public Health Departments, Alsancak Izmir, Turkey 


\section{REFERENCES}

1 Anon. Public research report on cigarette addiction and anti-cigarette campaign. PIAR Jan 1988; In Turkish.

2 Ferris BG. Recommended respiratory disease questionnaire for use with adults and children in epidemiological research. Epidemiology standardization project. Am Rev Respir Dis 1978;118:1-35.

3 American Thoracic Society. Standardization of spirometry 1994 update. Am J Respir Crit Care Med 1995;152:1107-36.

4 Levenberger $\mathrm{P}$, Schwartz J, Ackermann-Liebrich U, et al. Passive smoking exposure in adults and chronic respiratory symptoms (SAPALDIA study). Am J Respir Crit Care Med 1994;150:1222-8.

5 GOLD. Global strategy for the diagnosis, management, and prevention of chronic obstructive pulmonary disease. NHLBI/WHO workshop report. April 2001

6 Wilson R, Wilson CB. Defining subsets of patients with chronic bronchitis. Chest 1997; 12:303S-9S

7 Petty TL. Chronic obstructive pulmonary disease II. Hospital Physician $2001 ;$ Nov: $41-50$.

8 Schwartz J, Zeger S. Passive smoking, air pollution and acute respiratory symptoms in a diary study of student nurses. Am Rev Respir Dis 1990;141:62-7.
9 Comstock GW, Meyer MB, Helsing KJ, et al. Respiratory effects of household exposures to tobacco smoke and gas cooking. Am Rev Respir Dis $1981 ; 124: 143-8$.

10 Tredaniel J, Boffetta P, Saracci R, et al. Exposure to environmental tobacco smoke and adult non-neoplastic respiratory diseases. Eur Respir $J$ 1994;7:173-85.

11 Eisner MD, Smith AK, Blanc PD. Bartenders respiratory health after establishment of smoke-free bars and taverns. JAMA 1998;280:1909-14.

12 Xu X, Li B. Exposure-response relationship between passive smoking and adult pulmonary function. Am J Respir Crit Care Med 1995;151:41-6.

13 Masi MA, Hanley JA, Ernst P, et al. Environmental exposure to tobacco smoke and lung function in young adults. Am Rev Respir Dis 1988;138:296-9.

14 Eisner MD, Yelin HE, Henke J, et al. Environmental tobacco smoke and adult asthma. Am J Respir Crit Care Med 1998;158:170-5.

15 Masjedi MR, Homayoun K, Douglas CJ. Effects of passive smoking on the pulmonary function of adults. Thorax 1990;45:27-31.

16 Masi MA, Hanley JA, Ernst $P$, et al. Environmental exposure to tobacco smoke and lung function in young adults. Am Rev Respir Dis 1988;138:296-9.

17 Chen R, Tunstall-Pedoe H, Tavendale R. Environmental tobacco smoke and lung function in employees who never smoked: the Scottish MONICA study. Occup Environ Med 2001;58:563-8. 